\title{
Choosing ICT Tools: Proposition of a Model to Deliver Value for Clients
}

\author{
Paulo Grise', Melby Karina Zuniga Huertas²
}

\begin{abstract}
Several tools of Information and Communication Technology (ICT) are being used nowadays to support customer relationship processes. Literature review shows that, in the selection and deployment of these tools, internal goals of productivity and efficiency predominate. In just a few situations, the objective is offering higher value to the client. Therefore, the objective of this research was to propose a process of selection and deployment of ICT tools geared towards offering higher value, in the business to business market. Primary data were collected in depth interviews with high-level executives responsible for ICT areas. For the content analysis, the ATLAS-ti software was used, searching for recurrent themes. A value oriented process for choosing and implementing ICT tools was then proposed.
\end{abstract}

Keywords: information and communication technology; organizational market; relationship; information technology; value. 


\section{Introduction}

In this era of increasing turbulence in the market and intensifying competition, creating value for the client has become an strategic need. Only with superior qualifications to comprehend, attract and retain clients the companies can create more value and, therefore, stay aligned with the changing market demands (DAY, 200I). Here, value to the client is understood as an evaluation and a perceived preference related to the attributes of a product, the performance of these attributes and the consequences due to its use. These consequences may facilitate (or hinder) the ability of this client to achieve his goals and purposes in the situations where the product is used (WOODRUFF, 1997). Many different Information and Communication Technology (ICT) tools have been used by companies, in order to support their internal processes as well as those related to the relationship with clients.Various ICT tools are deployed for use by clients. The Business and Marketing literature on the subject shows, however, that internal goals of productivity and efficiency predominate in the selection and deployment of these tools. Only in a few situations prior research explores the contribution of the selection and deployment of ICT tools in the goal of generating and delivering value to clients in an orientation that is strategic to the market. This occurs specifically in business-to-business markets. Therefore, the objective of this research was to propose a process of selection and deployment of ICT tools geared towards offering higher value, in the business to business market.

With the intention to offer an elevated value, several apparatuses using ICT may be applied to business processes, notably to the processes of buying and selling (i.e. software for managing customer relations, internet, e-commerce portals, mobile phones, notebooks as a tool to support the work of a seller, among others) causing changes in the way the relationships between companies are conducted. From a theoretical perspective, empirical research, examining these firms' initiatives, may contribute to the ICT in B2B markets literature gap: little attention on value creation for the client in the selection and deployment of ICT tools. From a practical perspective, empirical research on the subject could help firms to improve the choice of ICT tools and to increase the success rate of these efforts. It may also indicate ways that align strategic intention and actual practice of the companies. Hence, this article reports an exploratory study where, starting from the analysis of real processes of selection and deployment of ICT tools in the Business to Business market (B2B), a proposal for a process oriented to offer higher value to clients is made.

\section{ICT and value to clients}

The literature review shows that companies use heavily, and increasingly, ICT tools. However, it is not possible to understand the contribution of such use in the whole process of building value to clients. Most studies on the use of ICT tools made outside Brazil focus only in some components of this process: i) cost reduction (Kaufmann and Carter, 2004; Barwise and Farley, 2005; Song and Zahedi, 2006; Long, Tellefsen and Lichtenthal, 2007; Michael, 2007; Rao, Senecal and Le, 2007; Tao., Chen and Chang, 2007; Kotabe, Mol and Murray, 2008; Samiee, 2008; Walters, 2008; Wu and Hisa, 2008); ii) information quality and speed (Ahearne, Jelinek and Rapp, 2005; Bush, Moore and Rocco, 2005; Honeycutt Jr, 2005; Papastathopouloua, Avlonitisb, and Panagopoulosc, 2007; Basu and Muylle, 2007; King and Burgess, 2008; Samiee, 2008); iii) productivity raise, efficiency and effectiveness of the commercial team (Bush et al., 2005; Buehrer, Senecal and Pullins, 2005; Schillewaerta, Ahearneb, Frambachc and Moenaertd, 2005; Ahearne et al., 2005; Honeycutt Jr, 2005; Long et al., 2007; Richards and Jones, 2008; Stein and Smith, 2009). Only two studies look at the whole process of construction of value to the Client (Long et al., 2007; Stein and Smith, 2009) and four address the issue from the point of view of the client instead of from the internal point of view of the supplier company (Celuch and Goodwin; Taylor, 2007; Marwaha and Willmott, 2006; Rao et al., 2007; Tao, Chen and Chang, 2007).

Among various models of value creation for clients, the Day's (200I) stands out. It consists of approximately twenty essential sub-processes grouped into five families: I) Definition of Value; 2) Integration and Resources; 3) Development of Value; 4) Delivery of Value; 5) Maintenance of Value. The value is defined, developed and delivered to the clients. The processes for Definition and Development of Value produce criteria and strategic foresight that are linked to resource allocation and to activities for the organization control. The process of Delivery of Value corresponds to the work of selling the product or of providing service, the front line of a business. The Maintenance of Value, on the other side, covers the work of after-sales support services, such as use, exchange or maintenance of a product, as well as other support services that ensure customer satisfaction and their perception of the value delivered by the supplier. The market response leads to activities that maintain and strengthen the whole process, leading to the renewal of the value proposition. Strengthening market orientation, in the view of Day (200I), is directly associated with building skills and being structured according to the processes that build superior value for clients. 
Having as axis the model for the process of delivering value to customers proposed by Day (200I), the mapping of all academic articles found on ICT, Business and Marketing was accomplished.The selection of publications used the international classification published by the Academy of Marketing Science as basis, and the best five publications were chosen. To these, two other publications specialized in business to business marketing were added, also with the best classification in the general ranking. Among the national publications, the ones that classified into at least level B2 in the Qualis Journals System of the Coordination for Improvement of High Education Personnel (CAPES) in Brazil were chosen. These are the national publications with the highest impact in the academic area of Business. All articles and papers related to the use of ICT tools were read, analyzed and ranked. The focus on the level of contribution of these tools to build value for clients guided the choice of publications related to management and marketing. Journals specialized in IT were also analyzed, but most of the articles were more linked to technology than to the relationship with clients.

The list of articles founded in the above bases were indentified with a number and classified into four groups: i) international academic journals, linked to Industrial Marketing (Business to Business) (Figure I); ii) international academic journals, linked to Consumer Marketing (Figure 2); iii) Brazilian academic journals (Figure 3); iv) Brazilian congress pro- ceedings (Figures 4). For each group a map (Figures I, 2, 3 and 4) is presented, showing the identification number of the article and its main theme, within the process proposed by Day (200I). For instance, article number 23 of the group "i" (first in the upper left corner of Figure I) has as its central theme the Factors for Selecting Suppliers of ICT. Due to limited space, the complete bibliographic relation of the articles ranked in the maps is not included in this article. It is, however, available by requested to the authors.

Among the 69 studies that comprise the first group, only two articles (4I and 58 on the map of Figure I) (Long et al., 2007; Stein and Smith, 2009, respectively) were found dealing with the use and application of tools of this nature on the whole Day's Process of Delivery of Value for Clients. The first one analyses the possible uses of the internet in the process of selling B2B. It shows how the internet could contribute to obtaining and transmitting information, and it establishes various proposals for the evaluation of internet use in the process. In these propositions, the authors suggest that integrating the internet into the B2B sales processes contributes to the efficiency of sellers and buyers, and that this positive impact is greater when the geographical distance between seller and buyer is big. They also consider the hypothesis of the internet use increasing the seller's motivation and, consequently, its effectiveness. This, in turn, could increase the satisfaction and effectiveness of the buyer, pro-

\section{ICT ARTICLES FROM INTERNATIONAL SCIENTIFIC JOURNALS, ORIENTED TO INDUSTRIAL MARKETING}

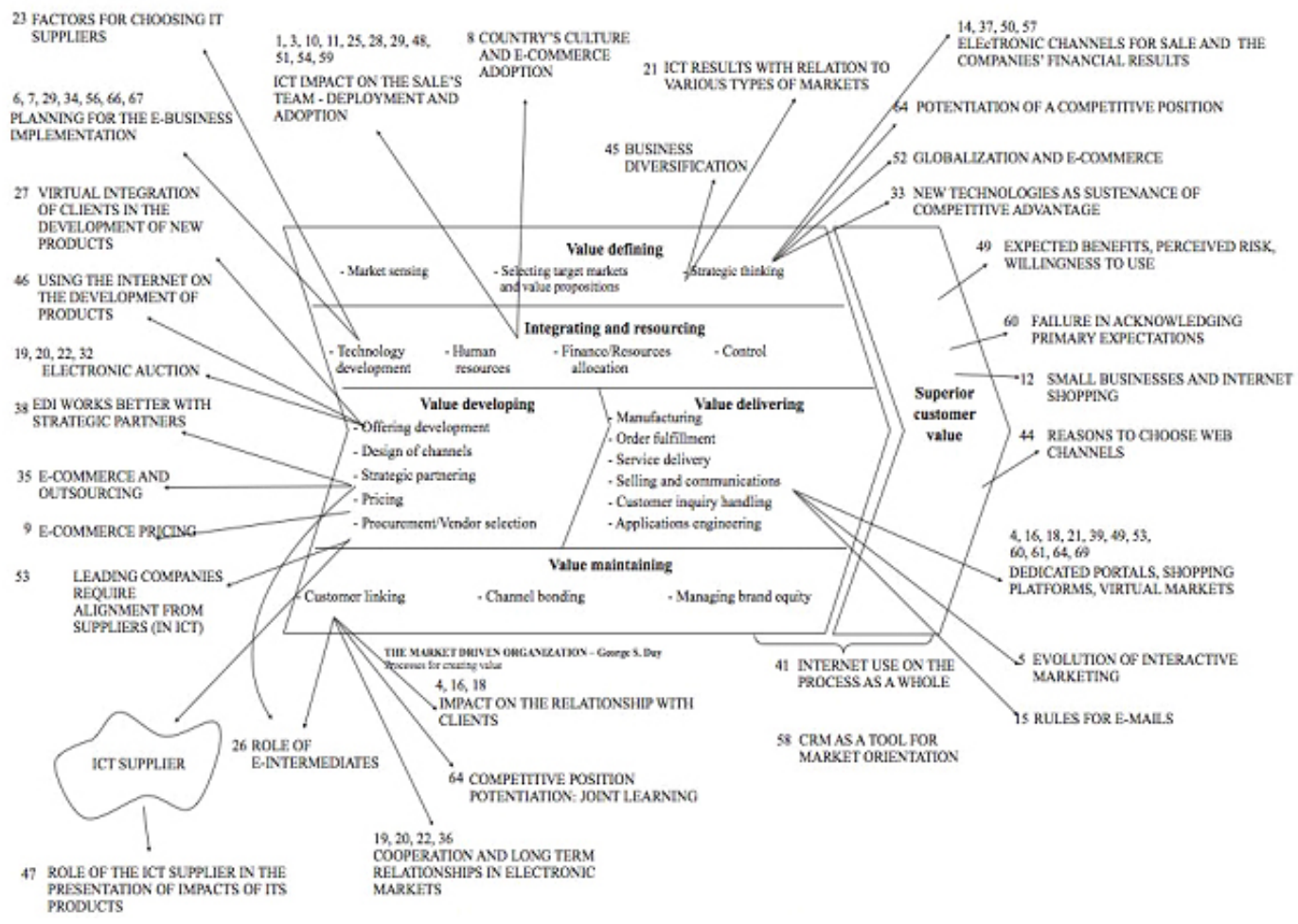

Figure I ICT articles oriented to Industrial Marketing and their relation with Day's process. Source:Author

ISSN: 07I 8-2724. (http://www.jotmi.org)

Journal of Technology Management \& Innovation (c) Universidad Alberto Hurtado, Facultad de Economía y Negocios. 


\section{ICT ARTICLES IN INTERNATIONAL SCIENTIFIC JOURNALS, CONSUMPTION ORIENTED}

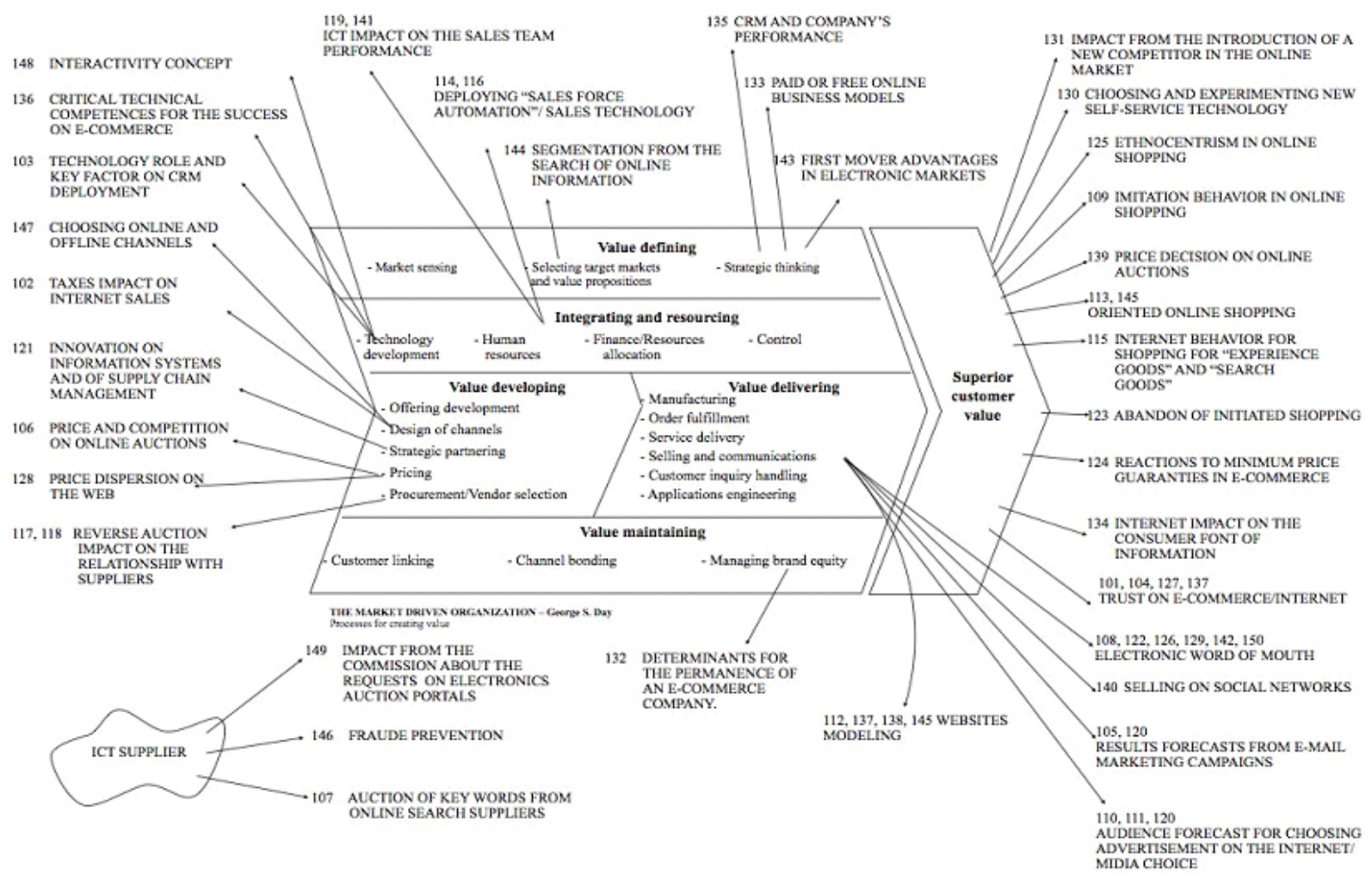

Figure 2 ICT articles in interational scientific journals, consumption oriented and their relation with Day's process. Source:Author

ICT ARTICLES IN BRAZILIAN ACADEMIC JOURNALS

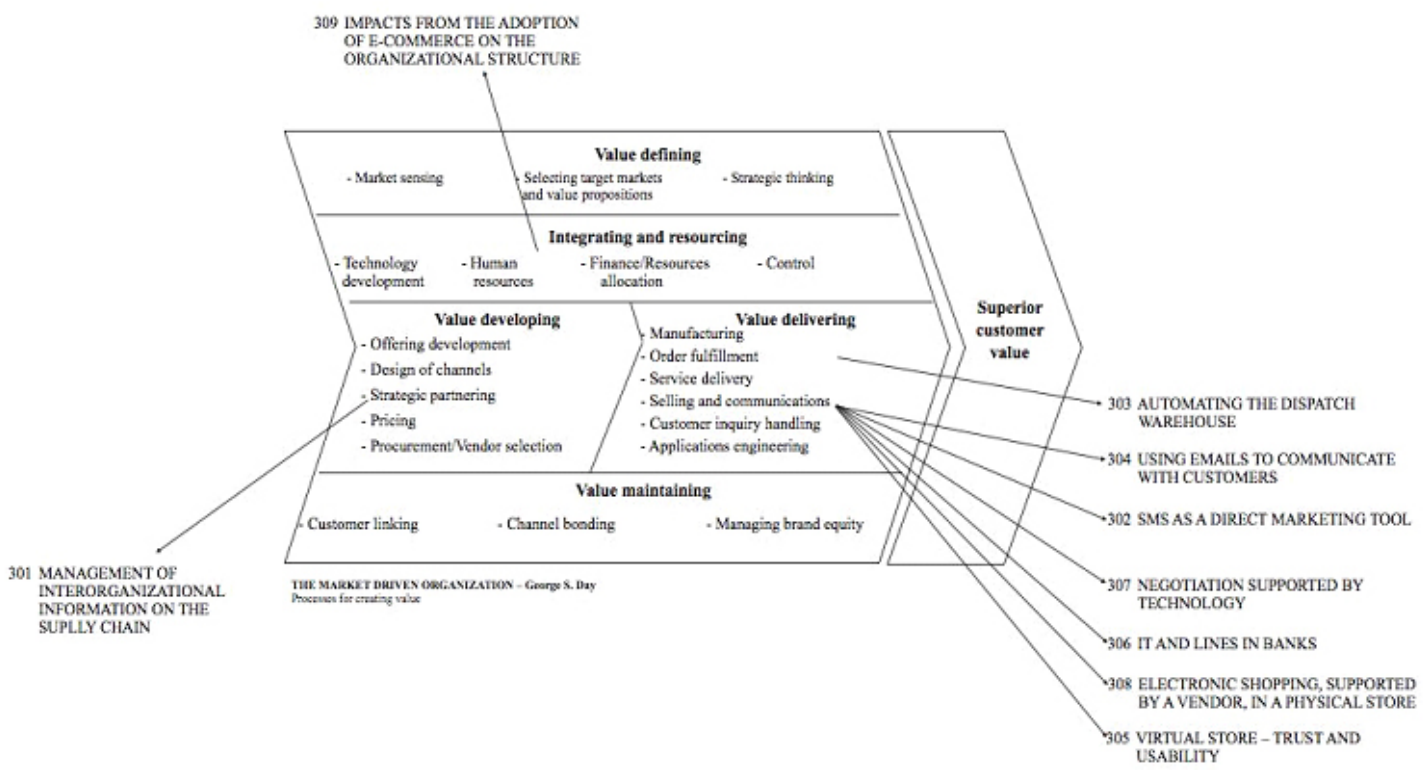

Figure 3 ICT articles published in Brasil and their relation with Day's process. Source:Author

ISSN: 07 I8-2724. (http://www.jotmi.org)

Journal of Technology Management \& Innovation (c) Universidad Alberto Hurtado, Facultad de Economía y Negocios. 


\section{ICT ARTICLES PRESENTED IN BRAZILIAN CONGRESSES}

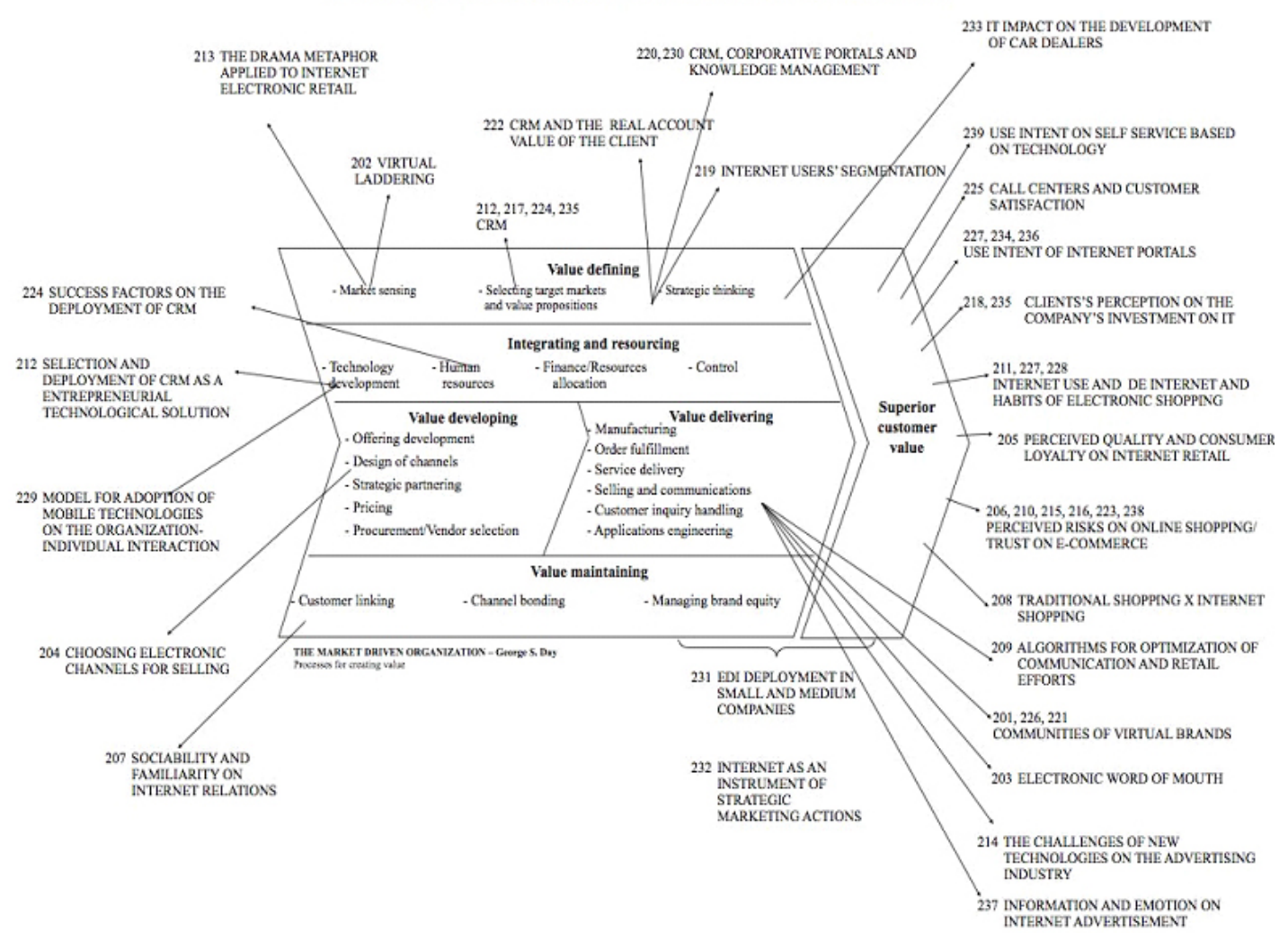

Figure 4 ICT articles presented in Brazilian congresses and their relation with Day's process. Source:Author

viding, to the sellers' company, higher customer retention, greater participation in customers' purchases and greater financial results. However, neither of these propositions is proven by empirical evidence. The most interesting contribution of this article is the suggestion to look at ICT as a tool that contributes to the construction of value for the client in every stage of the business process.

In the second article, Stein and Smith (2009) established a direct relationship between the use of CRM and a stronger firm's market orientation as a result of the process of collecting and structuring the information about clients. The authors also claim that the use of CRM improves the overall performance of the company. CRM, in this study, is understood as a consolidation platform for internal and external information about processes, customers and markets. Seen in this broad way, the CRM aligns the information that all areas of the company use in its internal processes and allows them to work to increase the value offered to clients.

Long et al. (2007) and Stein and Smith (2009) propositions were the inspiration for this research, because they show that the deployment of ICT tools may not only be motivated by internal goals (i.e. to reduce costs and increase productivity) as evidenced in the literature review. Theoretically, the deployment of ICT tools as a contribution to the process of building value to the client is possible; however, does it really happen in business? In search of empirical evidence that supports this conjecture, research aimed in analyzing the process of choice and deployment of ICT tools in the Business to Business (B2B) market was planned.

\section{Method}

The objective of this research was to propose a process for choosing and implementing ICT tools geared to offer higher value to clients. Driven by this goal and by the literature review, an exploratory research through in-depth interviews with executives of companies that use such tools was conducted. The following specific objectives were established: a) to examine how the commercial directors of the seller companies are using ICT tools in their business processes; b) to identify the ICT tools that are being used and their respective applications in sales processes between companies; c) to examine the (positive or negative) contributions offered by ICT tools, according to the seller companies' perception; d) to establish the possible relationships between the contributions of ICT tools and the Construction Process of Value for Clients; e) to understand the basis for the selection and deployment of ICT tools.

ISSN: 07 I8-2724. (http://www.jotmi.org) 


\section{Participants}

Firms and participants were chosen by convenience. The names of companies and respondents are not disclosed in this article. Company $\mathrm{A}$ is a corrugated cardboards and packaging manufacturer with 1.600 employees and US $\$ 200$ million annual net revenues. Company $B$ is a copper products manufacturer with 2.000 employees and US $\$$ I.0 billion annual net sales revenue in domestic market. Company $\mathrm{C}$ is a multinational telecommunication firm with more than 20.000 employees that provides fixed-line and mobile telephone services as well as broadband Internet services to 10 states along the western and southern part of the country, counts about 8 million landline customers, 7 million mobile customers, and 2 milion Internet subscribers. Its annual revenue is around US\$ I.5 billion. The positions of the interviewed executives were: i) Company A - Business Director for Paper and Packaging; ii) Company B - Superintendent iii) Company C - Vice President.

\section{Procedures}

The interviews were conducted between August and September 2010 at the respondents' offices, recorded with permission and transcribed. The interview script was elaborated based on the theoretical framework already discussed. The Process for Delivery of Value for Clients proposed by Day (200I) was presented graphically and discussed with the interviewees. At each stage of the process, the ICT tools used by the company and offered to its clients were identified. Subsequently, for each tool used by the company, the following topics were addressed: i) the reasons why it was chosen; ii) the expectations on the benefits it would bring to the company; iii) the expectations on the benefits it would bring to the clients; iv) how it was used by the company; v) how it was used by the client; vi) the positive aspects of its use for the company; vii) the positive aspects of its use for the client; vii) the negative aspects of its use for the company; ix) the negative aspects of its use for the client; $x$ ) the results of its deployment (such as productivity, resource saving, agility, flexibility, relationship, influence on profits, increase on sales, increase on the number of sold products, increase on customer base etc.).

\section{Data analysis}

For the analysis of the interviews we used the support of a software. Computers facilitate the analysis work, but do not provide the creativity and intelligence that make qualitative analysis unique. Softwares provide speed for encoding subjects, grouping data, defining categories, comparing interviews excerpts (PATTON, 2002). In looking for these benefits, the software chosen was the ATLAS-ti. Inductive and deductive techniques for content analysis were applied on the data obtained in the interviews, searching for patterns or recurring themes.

The analysis followed the methodology recommended by Corbin and Strauss (2008). The texts were read, parts of sentences were highlighted, and basic concepts were linked to these highlights. Throughout the reading and analysis, ideas and considerations of all kinds were being recorded in memos. The analysis followed with an investigation of the relationships between the basic concepts and their consolidation into themes.

\section{Content Analysis}

The content analysis of the interviews resulted in the following nine topics of interest.

\section{Context}

The directors interviewed suggest that the context found in the company is critical to the decision of deploying ICT tools. The company's situation in its relationship with customers, competitors, its internal environment, and its stage of technological development are components of the context that led the directors interviewed to make decisions on the deployment of ICT tools. The context is made up of issues such as: the technological gap relative to its competitors, the internal deficiency of information, the operational difficulty, the company's posture, the structure and form of customer service. The context appears as the main element to detonate processes of deployment of ICT tools.

\section{Strategic intent}

It is possible to recognize a strategic intent in the statements from the commercial directors interviewed. At Company $A$, there was a willingness to change the positioning of the company out of an image of "lagging, from a technological point of view", become better known by customers, prove itself organized, have an efficient interface with the customer, collect all customer information in a single platform, develop some operations and increase profitability. At Company B, the focus was to change significantly the company's performance, increasing the speed of response to the market. Here, the ICT tools didn't have this direct responsibility, but were used to support strategy changes that intended to "make people think about the client and look at customer service as a process that integrates several areas of the company." The ICT tools allowed sales teams and application engineering teams to be more focused on innovat- 
ing and building more lasting relationships with customers. The strategic intent comes before the choice of tools and facilitates the success of its deployment. The strategic intent compose, along with the context, another ground for the decision and choice of ICT tools.

\section{Tools used}

Various tools were deployed in the companies interviewed, three of them accesses for clients to consult information about processes and products from the supplier company, place their orders, view their statements of payable bills, and follow their orders and deliveries. The other tools deployed by the firms interviewed had as user someone from the internal team, as the following examples show.

Laptops and Blackberry like multifunctional mobile phones were available to vendors. In these devices, one of the companies implemented an online budget system through a software that allows the seller to set the price of a new product requested by the customer during a visit and in the presence of the client, discussing all the variables related to the product and services that the customer expects to receive.

Other tools used by the companies interviewed were a programmable automatic telephone service unit, which serves and directs calls according to a set of established rules, and a video conference system between manager and client. In logistics, it was mentioned both a computerized inventory addressing system associated with a bar code collector to identify the products and a software - Logistic Cockpit for the management of freights, trucks, shipping, transportation, and delivery of products. For business prospecting it was developed a transmission system (via cell phone) for sales opportunities of building materials - the register of construction sites. Covering various processes for communication and operation, a satellite interconnection between a franchisor company and all its franchisees was installed, for online communication, in real time, of data, voice and image. The tools are connected to different phases of the Process of Constructing Value for the Client, as can be seen in Figure 5, below. The majority of tools deployed were chosen primarily to solve internal issues related to organization, productivity or cost, even though they indirectly contribute to deliver Superior Value to the Client.

Of all these tools, only the Portal for the Client, called "The Company A Online", and the Special Area on the website for Building of Company B were developed as Customer Services. However, it was not taken into account whether the clients wanted or perceived value in these initiatives. The decision, in these cases, was from the supplier, without the direct participation of clients in the conception of the service.

\section{Internal benefits}

The deployment of ICT tools, according to the interviewed companies, has provided many and different internal benefits. The internal organization was one of the main perceived benefits. Another point associated with the previous one is internal integration. ICT tools allow the entire organization access to the same information about clients and therefore a better understanding about its participation in the service process and in the relationship with them. In the perception of respondents, internal communication is another point that evolves positively with the deployment of ICT tools. Wide benefits arise with the use of communication tools dedicated to interconnect the parent company with its various retail outlets. The systems applied to the processes of storage, routing deliveries, shipping, and transportation also showed benefits, in view of the interviewed - cost reduction, inventory reduction, reduction of workplace accidents. Internal integration is also seen as a tool useful to prospect new customers. The biggest emphasis, however, is in the benefits for the commercial team, for the sellers. Mobility: to work and have access to customer information and processes anywhere and to be available to assist the customer at any time are seen as primary benefits. Reducing the time the seller spends doing dull or less noble tasks is a fundamental role of ICT tools as well. Another perceived convenience is in the process of product pricing.

\section{Benefits for the clients}

In the perception of respondents, benefits for customers are much smaller than internal benefits. In general, operational facilities offered to customers are seen as benefits. There is no direct association with higher sales, increased revenue, enhanced reputation, increased customer influence in your market, better brand image, or profit growth.

In this operational level, in the view of respondents, it appears as benefits for customers the access to operational and financial information, and to the progress of orders. Easy and agile information about products is another positive aspect reported by the respondents. The relationship with clients gain agility with the possibility of immediate response offered by ICT tools. The delivery service also becomes more agile, and customers receive their products quicker. The Internet portal that the clients can access also becomes a tool for communication, and the client learns more about the supplier. The clients begin to use it as an essential tool for their jobs.

\section{Other indirect benefits}

The platform from Company A for communication with the client was also interesting for the relationship with vendors and suppliers, within the same concept of centralizing in-

ISSN: 07 I8-2724. (http://www.jotmi.org)

Journal of Technology Management \& Innovation (c) Universidad Alberto Hurtado, Facultad de Economía y Negocios. 
teresting information to this audience and standardizing the technical information and the production information, providing organization and reliable information.

In the case of pricing tools, the goal was to preserve margins and profitability for the company, but the system ended up generating additional unexpected results, such as a perception of exclusivity by the customer: "The client realizes that his product is unique, distinctive, it is a specialty. This is the concept that stays." The fact that the system of pricing presents in detail all technical characteristics of the product and the various alternatives for basic services offered to clients gives the seller the opportunity to thoroughly discuss the composition of the offer that he is making to the client. There was also the benefit of the agility in answering the client: the price is determined during the product definition and negotiation of services.

For the Commercial Director of Company A, one of the key points of the whole adoption of ICT tools was "to take the seller out of this mess of running to catch requests, give production information, see if it was billed, etc."

In Company B it was not different: "The technology comes to end questions like: is it ready, can I pick it up, is it delayed, is it billed?" Definitely the sales force benefits from the automation of routine tasks and from the possibility of greater dedication to the relationships with chosen clients.

\section{The relationship with clients}

The Superintendent Director of Company B made it clear that the tools deployed were intended to allow a major restructuring in the process of service and relationship with clients: "The big issue that prevented growth was the continuity of service practices. How will we grow if we always do the same things for the same customers?" From the availability of tools to automate the seller's routine tasks, it was possible to give sales and application engineering teams different assignments geared to build longer lasting relationships. To build value for the client was not the first consequence to ICT tools, but only with the deployment of these tools could the team be more available to seek ways to provide this higher value.

Also heard that same interview: "The construction and engineering companies participate in technical meetings with our team and the results go to the website. We bring our clients to visit the company B. They have then an understanding of our process, of care with our product. This brings a positive response. They value copper as solution". In yet another excerpt: "EDI, Internet and Intranet, this technology available to the vendors is a tool for a process. Clients still want great presence. Our application engineering is always face to face, by definition." Once more the strengthening of a personal relationship as a way to create and deliver more value to customers.

Company $C$ says it is changing its strategy: "Company $C$ is undergoing a transformation in its positioning. It always had a technical profile turned to technology and communication. Today, we are thinking about how to expand the business base of our clients and how to increase their efficiency." This is a clear statement that it intends to become more market oriented. The company is a major provider of telecommunication services, and it did not present, during the interview, any ICT tool that it has deployed, and it reiterated: "The philosophy of Company $C$ is that a major client should always speak with people ready to serve them. We have not outsourced our call center."

The basis to be more market oriented and to create value for clients, in the companies interviewed, is the personal relationship.Technological tools only support these processes.

\section{Perceived difficulties}

The respondents gave much emphasis to the process of adoption of ICT tools. The difficulties of adoption happen both internally and by the customers. The main points that emerged from the interviews are listed bellow.

ICT tools alone do not solve internal problems of the company, they automate existing processes and expose the degree of organization of this company. Companies that are disorganized or have bad processes will be more vulnerable if they open easy access to their information. Its precariousness and its flaws will become more visible. The risk of the customer noticing a decrease in the value of the offer is high. Customers offer resistance to the use of tools provided by suppliers:"We realize that clients are also very conservative and many have difficulty using the portal. The fight is for the client to use the portal. The client does not want to use it, but usage is growing." This is a sensitive point and care should be taken so that the customer uses what the company is making available to him.

One factor that determines the success of the tool is adoption. If this has often been difficult in an internal environment, obtaining customer acceptance is even more complex: "For a year and a half we had to go there and advise the client, train the client to use it." Without this effort, the result would not be the same.

Another key point is the union of the knowledge of ICT tools with the understanding about what value is in the perception of customers. In the voice of one of the respondents: "The bottleneck is the IT staff. They do not know how 
to think in business. Nobody discusses in a serious way how technology can support business. The secret is how to connect the client to the company." And again: "The great difficulty is that the CIOs - Chief Information Officers - are not connected to the client. Marketing directors are connected to clients, but do not know what technology can offer. We (ICT providers) end up having to figure out what to do to develop the customers' operation."

\section{Value for the clients}

The analysis of the interviews gave indirect indications of the effects of the deployment of ICT tools that may be seen as valuable by the clients of these companies.

This section has an error of origin: customer value requires the client to be heard. Only the customer may answer what truly is value in their sight. Clients were not interviewed, so it would not be legitimate to speak on their behalf. $\mathrm{Nev}$ ertheless, in the interviews of the commercial directors it was possible to identify clues about what can be understood as value for the clients, in the opinion of the respondents. These clues are classified below taking into account the five categories of value - functional, social, emotional, epistemological and situational - proposed by Sheth, Newman and Gross (1991 apud Woodruff, 1997).

A summary of what was considered value for the client, in this analysis based on the opinion of the respondents, is structured in Figure 5.

\section{Functional value}

\section{Discussion and proposal for a process of chose and deployment of ICT tools}

The decision to deploy ICT tools, in general, involves different areas of a company. In the process of building value for clients, marketing, business and technology will take part in the decisions. In many cases, specific areas in which you want to apply ICT to their processes - logistics, for example - will also participate in the decisions. The knowledge and inter-

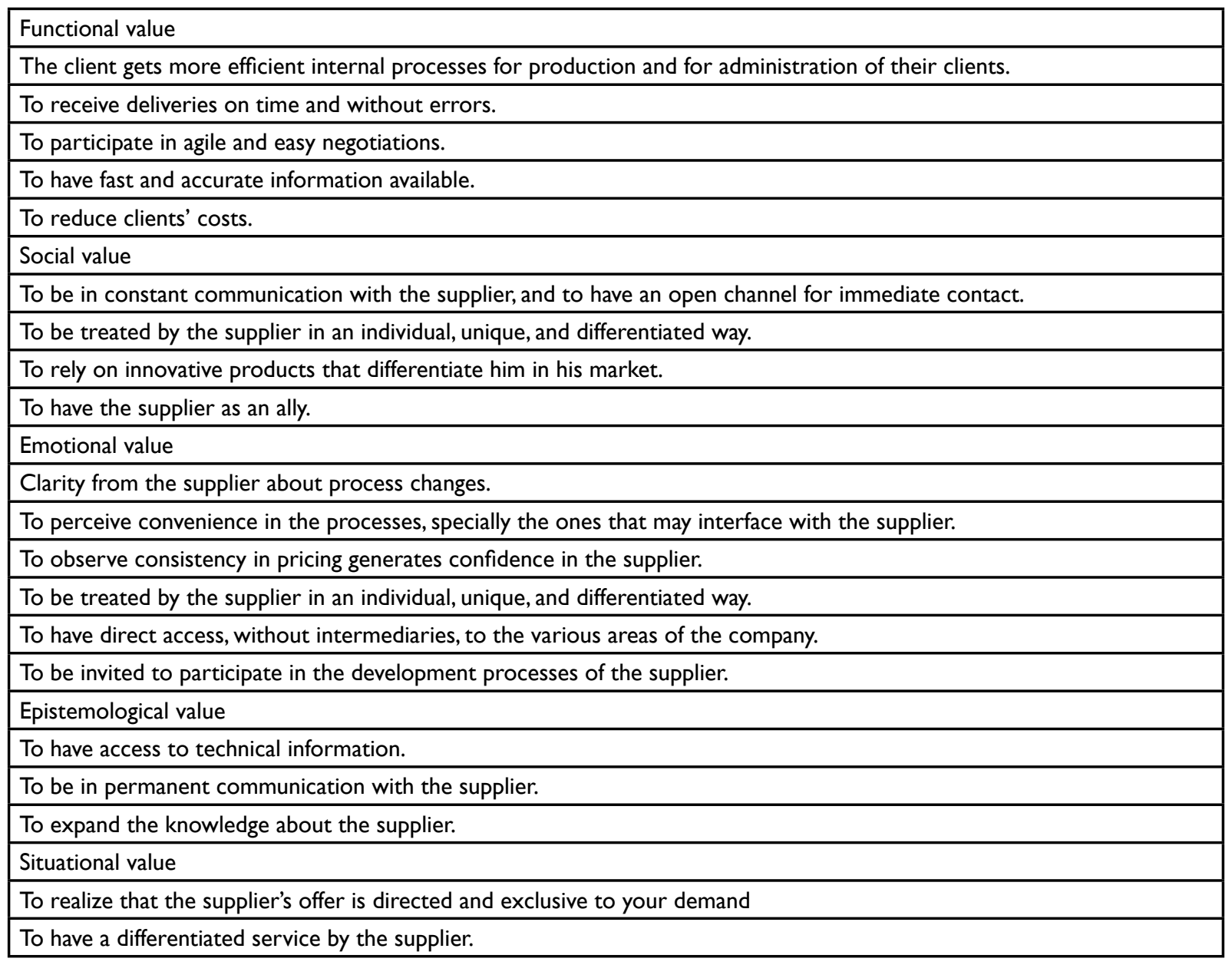

Figure 5 -Value for the client, in the perception of the respondents

ISSN: 07 I8-2724. (http://www.jotmi.org)

Journal of Technology Management \& Innovation (C) Universidad Alberto Hurtado, Facultad de Economía y Negocios. 
ests of each involved area are different. The technology area will certainly know a lot of tools, but will not know whether or not they contribute to the value offered to the client. A specialist area will know very well about its processes, but it will not know enough technology to be able to decide alone which tools to deploy. Multidisciplinary decisions, involving different interests and skills, work best within a structured process.

Throughout the interviews, themes related to the process of choice and deployment of ICT tolls emerged spontaneously. The analysis and structure of the interviews made clear that there is a set of cautions and concerns that the managers interviewed took or recommended that they should be taken. These themes suggest a process for the adoption of ICT tools that, being based on practical experience, may result in great accuracy and ease in its choice and deployment.

Because of the interview roadmap, based on the theoretical framework studied, we expected that the themes "Internal Benefits", "Benefits for the Clients" and "The Relationship with Clients", related to the tools used and their benefits, would emerge in the interviews and that they would form the basis for the conversations with interviewers. However, the interviews were richer by bringing new elements related to the Context of the company, its strategic intent, details and care with the deployment and the monitoring of results and adjustments after the implantation.

Decision making on ICT tools, in the theoretical framework analyzed, is heavily based on internal benefits and oriented to specific aspects of the processes of building value. In most cases there is no clear market orientation as a strategic base for the decision. The proposed process (Figure 6) starts by understanding the context of the company and recognizes the initial state of value offered to clients. Starting from there, it develops the strategic intent and facilitate choices, giving focus to the deployment of ICT tools, avoiding failures, setbacks, losses, and allowing clarity to the contributions and expected results of these deployments, putting ICT at the service of the strategy of really orienting itself to the market. Another interesting consequence is the possibility of aligning, through this process, the skills and interests of the different areas of the company involved in the decisions and deployment of ICT tools.

Considering the high investment and rapid growth of the applications of ICT tools in Brazilian companies, the adoption of a process as the one proposed could result in a reasonable saving of financial resources and in the reduction of efforts and of personal waste for companies.

The use, although a in a first and basic level, of concepts from Grounded Theory in the interviews showed the potential of this research and analysis process. The application of software for the content analysis of the interviews also showed the high capacity these tools offer in order that qualitative data may be analyzed from various angles and different aspects, contributing for the analysis process to become more efficient, rich and consistent. Among researchers, in Brazil, there is scope to expand the knowledge about ICT tools and their impact on corporate strategy, especially in the not really well studied relations defined as business to business. The small number of in-depth interviews that supported the propositions of this study suggests that more information is sought to consolidate these proposals. one can start, however, at a higher level of understanding of the processes of deployment of ICT tools. One immediate suggestion is to take the process proposed to be presented and discussed with managers of commercial areas, areas of marketing and of technology from other companies. These professionals certainly can contribute for its enhancement. Another potential avenue is to interview customers in order to learn about their perceptions of value for what their suppliers offer in terms of ICT tools. This clients' view will also make the process of choice of tools more focused on value for the client. 


\section{Process for choosing and deploying ICT tools}

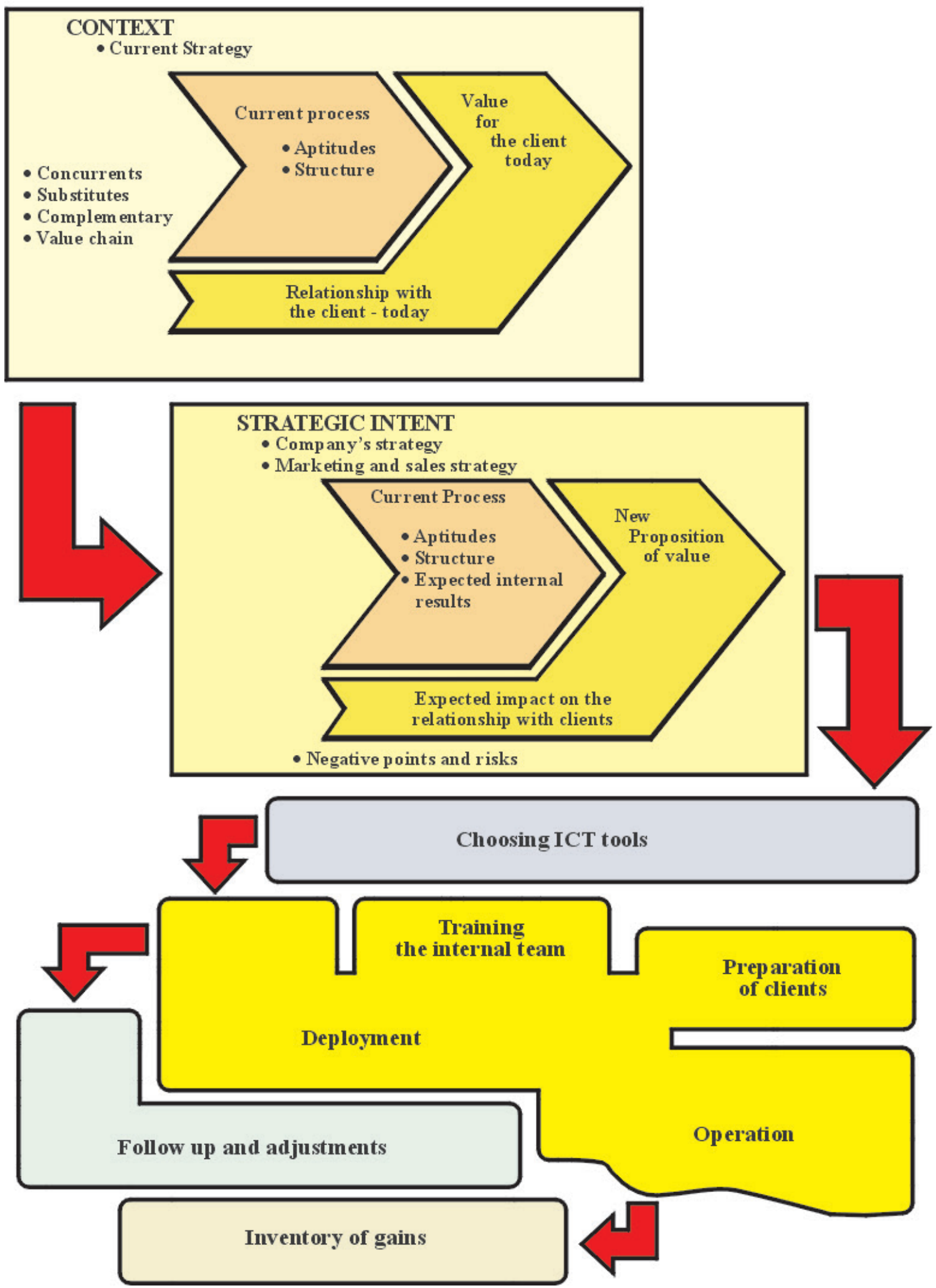

Figure 6. Proposal for a process of chose and deployment of ICT tools. 


\section{Bibliography}

AHEARNE, M., Jelinek, R., Rapp, A. (2005). Moving beyond the direct effect of SFA adoption on salesperson performance: training and support as key moderating factors. Industrial Marketing Management, 34, 4, 379 - 388.

BARWISE, P., Farley, J.U. (2005). The State of Interactive Marketing in Seven Countries: Interactive Marketing Comes of Age. Journal of Interactive Marketing, 19, 3,67 - 80.

BASU, A., Muylle, S. (2007). How to Plan e-Business Initiatives in Established Companies. MIT Sloan Management Review, 49, I,.28 - 36 .

BUEHRER, R. E., Senecal, S., Pullins, E. B. (2005). Sales force technology usage - reasons, barriers, and support: An exploratory investigation. Industrial Marketing Management, 34, 4, 389 - 398.

BUSH, A. J., Moore, J. B., Rocco, R. (2005). Understanding sales force automation outcomes: A managerial perspective. Industrial Marketing Management, 34, 4, 369 - 377.

CELUCH, K., Goodwin, S., Taylor, S. A. (2007). Understanding small industrial user internet purchase and information management intentions: a test of two attitude models. Industrial Marketing Management, 36, I, I09 - 120.

DAY, G. S. (200I). A empresa orientada para o Mercado: compreender, atrair e manter clientes valiosos. Bookman, Porto Alegre.

HONEYCUTT Jr, E. D. (2005). Technology improves sales performance - doesn'it? An introduction to the special issue on selling and sales technology. Industrial Marketing Management, $34,4,301-304$.

KAUFMANN, L., Carter, C. R. (2004). Deciding on the mode of negotiation:To auction or not to auction electronically. The Journal of Supply Chain Management, 43, I, I5 - 26.

KING, S. F., Burgess, T. F. (2008). Understanding the success and failure in customer relationship management. Industrial Marketing Management, 37, 4, 42I - 43I.

KOTABE, M., Mol, M. J., Murray, J.Y. (2008). Outsourcing, performance and the role of e-commerce: a dynamic perspective. Industrial Marketing Management, 37, I, 37 - 45.

LONG, M. M., Tellefsen, T., Lichtenthal, J. D. (2007). Internet integration into the industrial selling process: a step-by-step approach. Industrial Marketing Management, 36, 5, 676-689.
MARWAHA, S., Willmott, P. (2006). Managing for scale, speed and innovation. The McKinsey Quarterly, 3, I5 - 21 .

MICHAEL, S. C. (2007). Can information technology enable profitable diversification? an empirical examination. Journal of Engineering and Technology Management, 24, I, I67 - I 85.

PAPASTATHOPOULOUA, P., Avlonitisb, G. J., Panagopoulosc, N. G. (2007). Intraorganizational information and communication technology diffusion: implications for industrial sellers and buyers. Industrial Marketing Management, 36, n. 3, 322 - 336.

PATTON, Michael Q. (2002). Qualitative research \& evaluation methods. 3. ed. Sage, Thousand Oaks.

RAO, S. S., Senecal, D.T. S., Le, T.T. (2007). How buyers expected benefits, perceived risks, and e-business readiness influence their e-marketplace usage. Industrial Marketing Management, $36,8,1035-1045$.

RICHARDS, K.A., Jones, E. (2008). Customer relationship management: finding value drivers. Industrial Marketing Management,.37, 2, $120-130$.

SAMIEE, S. (2008). Global marketing effectiveness via alliances and electronic commerce in business-to-business markets. Industrial Marketing Management, 37, I, 3 - 8.

SCHILLEWAERTA, N., Ahearneb, M. J., Frambachc, R. T., Moenaertd, R. K. (2005). The adoption of information technology in the sales force. Industrial Marketing Management, 34, 4, 323 - 336, mai. 2005.

SONG, J., Zahedi, F. M. (2006). Internet marketing strategies: antecedents and implications. Information \& Management, 43, 2, 222 - 238.

TAO, Y., Chen, C., Chang, C. (2007). Unmet Adoption expectation as the key to e-marketplace failure:A case of Taiwan's steel industry. Industrial Marketing Management. 36, 8, 1057 - 1067.

WALTERS, P. G. P. (2008). Adding value in global B2B supply chains: strategic directions and the role of the Internet as a driver of competitive advantage. Industrial Marketing Management, 37, I, 59- 68 .

WOODRUFF, R. B. (1997). Customer value: the next source for competitive advantage. Journal of the Academy of Marketing Science. 25, 2, 139 - 153.

WU, J., Hisa, T. (2008). Developing e-business dynamic capabilities: an analysis of e-commerce innovation from I-, M-, to $\mathrm{U}$-commerce. Journal of Organizational Computing and Electronic Commerce, I8, 2, 95 - III.

ISSN: 07I 8-2724. (http://www.jotmi.org) 